International Review of Research in Open and Distributed Learning Volume 18, Number 4

June - 2017

\title{
Higher Education Faculty Perceptions of Open Textbook Adoption
}

Eulho Jung, Christine Bauer, and Allan Heaps

Boise State University

\begin{abstract}
The high cost of tuition and textbooks can have a negative impact on potential students from lower socioeconomic backgrounds. Open Educational Resources (OER) offers students a way to save educational costs while utilizing high-quality open textbooks. Up until now, there have been few studies focused on a specific provider of open textbooks. This study investigates open textbooks provided by OpenStax. Specifically, this study uses the COUP framework to examine: (1) cost reduction, (2) outcomes, (3) uses, and (4) the faculty perceptions of the quality of OpenStax textbooks. Additionally, we expanded the framework to address (5) the relationship between the perceived quality of the OpenStax textbook and the faculty perception of student performance, (6) the faculty's intention to continue to adopt OpenStax textbooks, and (7) the perceived importance of accessibility to faculty who use OpenStax textbooks. Overall, the findings suggest that a significant amount of financial savings and a number of pedagogical shifts can be supported by the use of OpenStax textbooks.
\end{abstract}

Keyword: OpenStax, open textbooks, OER, perception of open textbooks

\section{Introduction}

Textbooks are an important part of the post-secondary college instructional model and can be expensive (Bok, 2009). One study found that the average textbook price was $\$ 90.00$ at seven different colleges across multiple general education courses that included science, mathematics, humanities, and business disciplines (Hilton, Robinson, Wiley, \& Ackerman, 2014).

The high cost of tuition and textbooks can have a negative impact on potential students from lower socioeconomic backgrounds (Paulsen \& St. John, 2002). Provasnik and Plenty (2008) found that high educational costs cause these individuals to be more prone to delay college enrollment than wealthier students. High textbook costs can also encourage students to take fewer classes per term, extending their 
time to graduation (Buczynski, 2007). A Florida Virtual Campus study conducted in 2012 reveals that 23\% of students choose not to purchase textbooks due to the high cost.

Open Educational Resources (OER), including open textbooks, are low or no cost instructional materials that are offered through some form of an open license (D’Antoni, 2009; Hilton \& Wiley, 2011). Based on the type of license associated with an open textbook these materials can be used whole or in part as a course text at a much lower cost, thus mitigating some of the negative impact to students of a more expensive published textbook.

Open textbooks have been available for more than a decade. Some instructors, departments, and institutions have redesigned courses and curriculum to include or rely entirely upon OER content (Bliss et al, 2013; Caswell, 2012; Hilton \& Wiley, 2011). While much has been done in recent years to create, increase awareness of and support for open textbooks, Bliss, Robinson, Hilton, and Wiley (2013) advocate the need to fill the gap in "theory-based, generalizable research" that examines the impact and uses of open textbooks. To provide such research they have effectively utilized a "COUP framework" (Cost, Outcome, Use, Perceptions), which allows us to understand the impacts of open textbook use on each of these important aspects of education. While the COUP framework incorporates perceived cost savings when using an open textbook, cost is not the only facet to consider to better understand the impact of open learning materials.

Allen and Seaman's (2016) national report, Opening the Textbook: Educational Resources in U.S. Higher Education, 2015-16, revealed that there are still a number of barriers to open textbook adoption; faculty have a hard time finding what they need and believe finding a traditional textbook is easier than finding an open textbook. Faculty also have recently become more concerned about the quality of the materials and less concerned about having permission to alter or use only part of a textbook (Allen, Seaman, Poulin, \& Straut, 2016).

Many OER research studies have focused on perceptions of OER use. While valuable, most studies have examined the perceptions of faculty using anything they considered to be OER. For example, research conducted by de los Arcos, Farrow, Pitt, Weller, and McAndrew (2016) reported findings from more than 600 teachers' perceptions of OER. Teachers mentioned a wide range of different types of OER, such as Ted Talks, Learning Modules, YouTube, iTunes, or Khan Academy. However, without having an operationalized definition of OER, it is difficult to validate findings (Nevo, 1985). Similarly, Bliss et al. (2013) conducted a study on OER user perceptions of 58 teachers and 490 students from Project Kaleidoscope (PK) institutions. While the study has a considerable number of respondents, the types of OER resources teachers used were not concretely defined. This is a problem across several OER-related perceptions studies (Hilton, 2016).

Pitt (2015) conducted a study involving educators who used OpenStax College open textbooks. The results of this research indicate that using OER can help educators better respond to students needs and make teaching easier. However, given that more than half of survey respondents are adopters of college physics, it is unknown whether the study represents general population of OpenStax textbook users. Moreover, while that study provides meaningful findings, it did not investigate the impact of OER on students. 
Unlike previous studies, the present study only focuses on OpenStax adopters and explores all aspects of the COUP framework. By targeting a specific group of users, this study ensures that all participants: (1) knew that they used open textbook as part of OER, (2) had a high likelihood of understanding the meaning of OER, (3) used open textbooks that had gone through the publication process, and most importantly, (4) reported their perceptions of open textbooks from OpenStax.

Additionally, with an increase in litigations pointed at educational institutions to ensure online materials are accessible to students with disabilities, it seems prudent to understand and increase faculty awareness and perceptions of the accessibility features of OER textbooks. OER providers are also concerned about accessibility of open textbooks. For example, BCcampus promotes the importance of ensuring accessibility for all students.

The focus of many open textbook projects is to provide access to education at low or no cost. But what does access mean? If the materials are not accessible for each and every student, do they fulfill the mandate to deliver fully open textbooks? (Coolidge, Doner, \& Robertson, 2015)

Finally, the impact of OER textbooks on student achievement (Bliss et al., 2013) and the relationship between faculty perceived quality and their intention to adopt OER textbooks have also been raised as areas for further study (OpenStax Representative, personal communication, August 10, 2016). Based on this context, the following research questions were developed for this study.

1. What perceptions do faculty have about the cost, outcomes, use, and quality when adopting OpenStax textbooks?

2. What perceptions do faculty have about the impact of OpenStax textbooks on student achievement?

3. What perceptions do faculty have about the importance of accessibility features when adopting OpenStax textbooks?

\section{Methodology}

The purpose of this study is to add to the literature related to adoption of educational innovations and in particular to the adoption and implementation of Open Educational Resources (OER), specifically OpenStax textbooks, in post-secondary environments. This study partially replicates and is based upon a previous study conducted by Bliss, Robinson, Hilton, and Wiley (2013), "An OER COUP: College Teacher and Student Perceptions of OER.” In addition, the current study focuses a specific population of faculty using open textbooks from OpenStax teaching at various higher education institutions around the globe, and contains survey questions related to faculty perceptions about the importance of accessibility features when adopting open textbooks and the impact of open textbooks on student achievement. For instrument validity, we developed the survey questionnaire in collaboration with multiple stakeholders including BCcampus, Babson Research Center, OpenStax, and Open Education Group. 


\section{Participants}

Participants in this study include faculty who adopted open textbooks through OpenStax (https://openstax.org/). OpenStax managers communicated with their post-secondary community about the survey in the form of emails in accordance with their privacy policies. All participants $(n=150)$ received an electronic version of the research consent form and were required to agree with the consent prior to the commencement of the survey.

\section{Instrument Validity}

Bliss, Robinson, Hilton, and Wiley's (2013) survey questions provided the basis for survey development and were modified and expanded to fit the purpose and scope of this study. To ensure instrument validity, survey questions were reviewed by multiple experts in the field, including:

- John Hilton, one of the leaders of Open Education Group and the pioneering author from the research upon which this study is based;

- Jeff Seaman, co-director of the Babson Survey Research Center, a nationally recognized center for the development and distribution of numerous annual educational technology related online surveys;

- Nicole Finkbeiner, Associate Director of Institutional Relations, and David Harris, Editor in Chief, at OpenStax, a nonprofit based organization at Rice University with a mission to improve student access to education through OER development and adoption;

- Amanda Coolidge, Senior Manager of Open Education from BCcampus, a Canadian based network supporting the British Columbia post-secondary system in the areas of teaching, learning, and educational technology, including OER; and

- Lauri Aesoph, Manager of Open Education from BCcampus.

The survey instrument was then modified based on expert feedback and delivered using an online survey format. The questionnaire included multiple-choice, multiple-select and open response items. Of the 31 survey questions, eight contained demographic related questions, three inquired about the cost of open textbooks compared to traditional texts, six related to faculty and student usage of open textbooks, eight questions inquired about student preparation and performance while utilizing open textbooks, five related to adoption and faculty perceptions of open textbook quality, and five questions related to adoption and faculty perceptions of open textbook accessibility features. Finally, seven adaptive follow up questions were included dependent upon participant responses to particular questions related to perceptions of quality and course preparation.

\section{Data Analysis}

A total of 150 survey responses were collected, and all of them completed the survey. After collecting online survey responses, the researchers utilized descriptive statistics to analyze the results and thematic analysis 
for open-ended questions. When facing conflicts of interpretation, the researchers held a series of dialogues to reach a shared understanding.

\section{Results}

Utilizing the COUP framework as the base for the study, additional components were added, including accessibility and perceptions of quality and student performance. This section presents the findings related to demographics, cost, outcome, use, perception of quality, and accessibility. For the quantitative and thematic analysis of the qualitative data, descriptive statistics were used.

\section{Demographics}

The respondents were $61 \%$ male and $39 \%$ female $(n=136)$. Data on the faculty status of the respondents revealed that the majority of the open textbooks adopters were full-time faculty (41\%) and full-time tenured faculty (35\%). Many of them taught at a community college (43\%) or public, four-year college or university (43\%) in the United States (92\%). The other almost $8 \%$ of the participants were located in Canada, South Africa, Bosnia Herzegovina, Italy, and Germany.

In terms of class format, $60 \%$ of the participants reported that they used open textbooks in face-to-face courses, while $16 \%$ used them in online courses and $24 \%$ used them in blended/hybrid courses. The major of the respondents adopted their open textbooks from OpenStax (77\%), followed by OER Commons (4\%), MIT Open CourseWare Online Textbooks (3\%), Lumen Learning (3\%), and others (7\%) (respondents were able to choose multiple options).

When designing the survey, the researchers were curious as to whether the OER adopters realized that open textbooks are a type of OER. The results showed that all but one participants were aware that the textbook was an open textbook at the time of adoption, indicating that the adopters made an informed decision when adopting the open textbooks. In terms of disciplines, nearly half of the faculty respondents reported that they taught in the field of sciences and environmental sciences (51\%), followed by the social sciences (23\%), mathematics, computing, and engineering (14\%). No respondent reported having taught in education, making it the field with the least number of open textbook adopters.

\section{Cost}

Cost saving is one of the most important factors in deciding to utilize open textbooks. Prior to using open textbooks, $70 \%$ of respondents believed that $50 \%$ to $90 \%$ of their students purchased the required course textbook (Figure 1). 


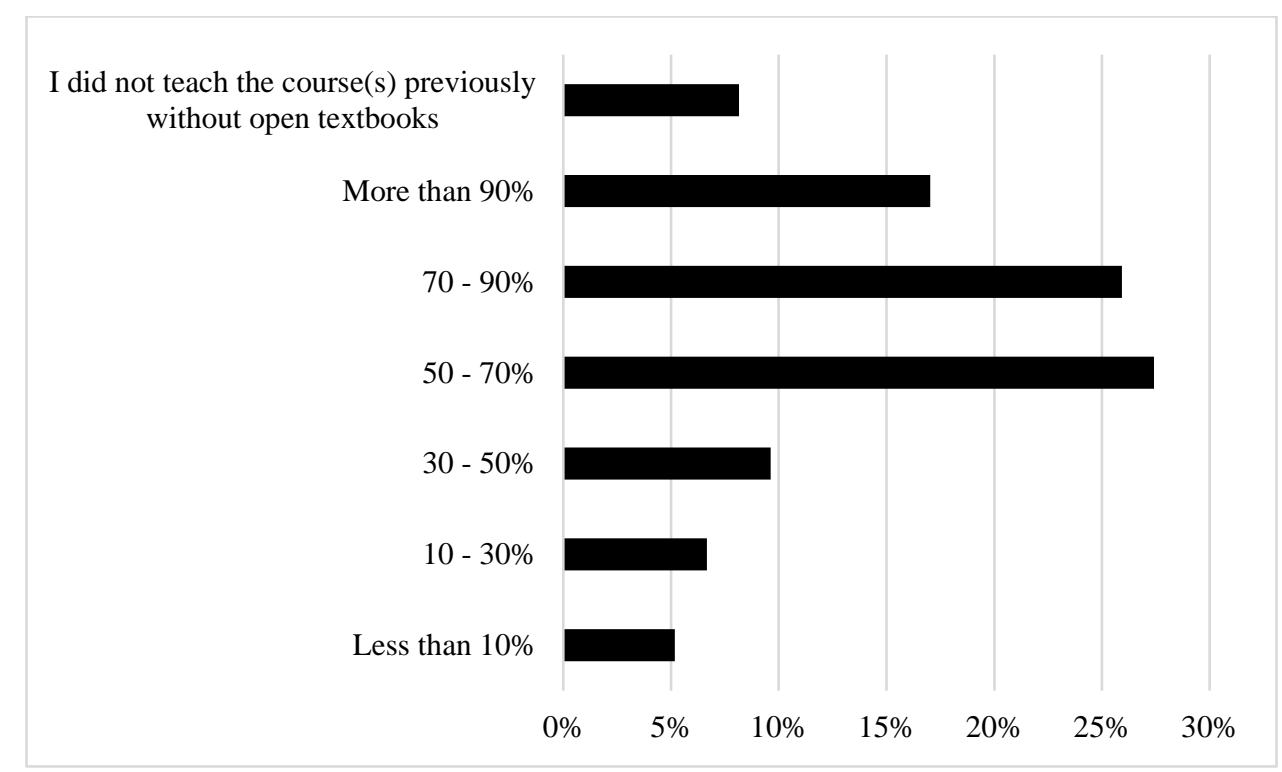

Figure 1. Percentage of students who previously purchased a textbook.

Data indicate that faculty members were aware of the importance of cost and more than $71 \%$ of the faculty members in our study checked textbook prices within the past 11 months (Figure 2).

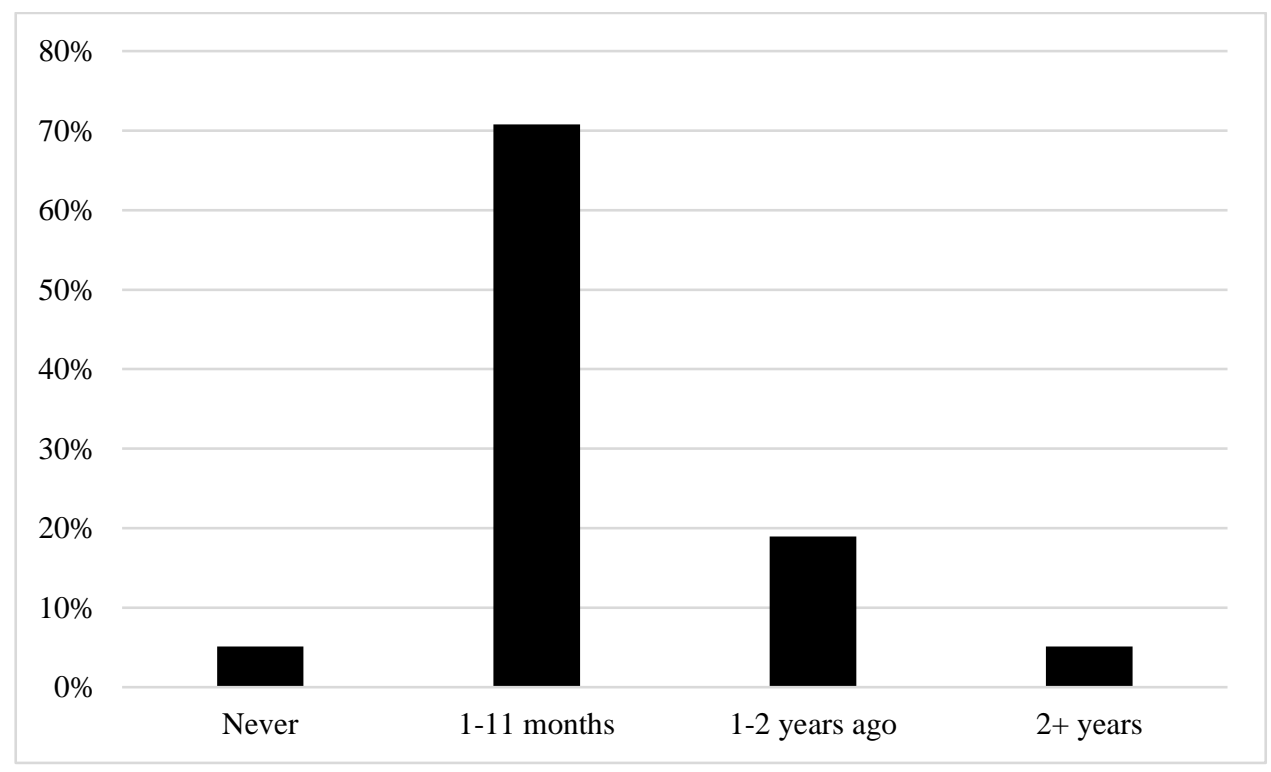

Figure 2. Last time faculty checked textbook prices.

Finally, $81 \%$ of faculty members in the study believed that without the use of open textbooks each student would generally spend $\$ 100$ or more per course on required textbooks (Figure 3). 




Figure 3. Faculty prediction of students' costs related to textbooks per course.

\section{Outcome}

Several questions explored faculty perceptions about how the usage of open textbooks impacted teaching and learning in four categories: (1) teacher preparation time, (2) instructional changes, (3) student preparedness, and (4) perceived performance. Responses to open-ended questions were thematically analyzed.

Teacher preparation time. Of the faculty members in our study, $82 \%$ stated that they spent about the same or less time preparing to teach a course using open textbooks, while $18 \%$ said that they spent more time. Figure 4 shows the percentage of faculty preparation time. 


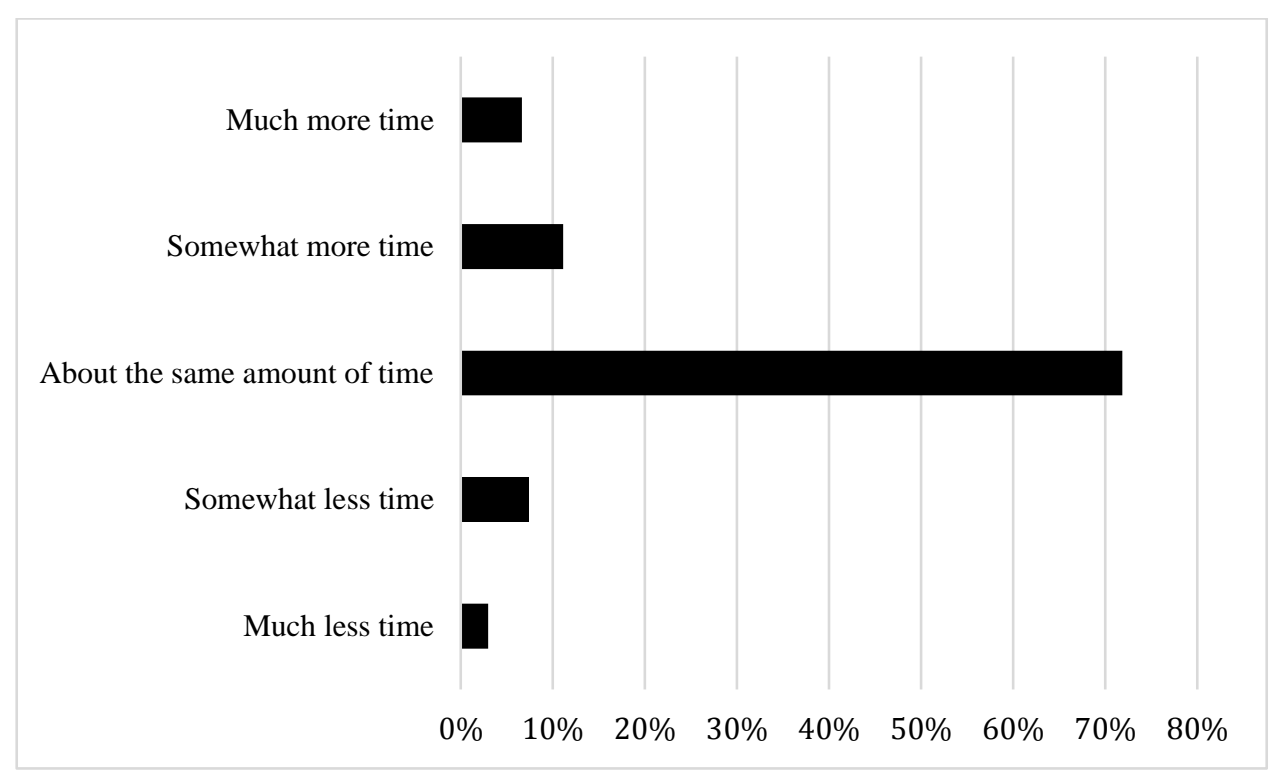

Figure 4. Faculty preparation time.

Those faculty members who "spent more time" (18\%) were asked a follow-up question in order to determine whether spending more time was acceptable. Of those faculty members who answered that the additional time was acceptable (78\%), they stated the following reasons: (1) immediate and ubiquitous student access to textbook, (2) up-to-date content, (3) interactivity, (4) textbook better aligned with class activities, (5) content quality, (6) faculty convenience, and (7) ability to customize/modify content. Faculty members who believed that spending more time was not acceptable (22\%) stated the following concerns: (1) lack of alignment between test banks and textbook content, (2) poor quality of text banks/quiz questions, (3) lack of student engagement, and (4) lack of instructor resources. Interestingly, engagement and alignment were common themes, but viewed differently depending on whether the faculty member approved or disapproved of the additional time spent.

Instructional changes. Many faculty reported little to no change in their instruction as a result of using open textbooks (52\%). However, some faculty believed using open textbooks enabled positive changes in their instruction. For example, several faculty indicated they started employing student-centered instruction such as collaborative and active learning strategies as well as implementing flipped classroom methods. These instructional approaches, in turn, helped the faculty members employ different types of assessments, enabled displaying/referring to the open textbook during class, or facilitated the use of applied examples/problems. Several faculty members mentioned they felt empowered to make these types of instructional changes due to the assumption that every student could access the open textbook on the first day of class. Other faculty commented that the ability to customize the textbook enhanced the relevance of the content to the student. Few negative instructional changes were mentioned. A couple of faculty responses indicated additional time was needed to deal with technology issues and to find and fix broken hyperlinks. 
Student preparedness. Similar to the results reported by Bliss et al. (2013), 68\% of the faculty members perceived their students as equally prepared for their course using open textbooks compared to using traditional textbooks. Another 20\% of the faculty members reported their students were more prepared when using open textbooks than when using traditional textbooks. Only $5 \%$ believed that their students were less prepared using open textbooks than when using traditional textbooks.

Perceived performance. Similar to the results on student preparedness, a significant portion of faculty members (23\%) believed their students performed better when using open textbooks, while a majority (64\%) thought that their students showed the same level of performance. Only $4 \%$ perceived that the performance of their students was worse than when using traditional textbooks. Nine percent of the faculty members reported that they had never taught the course without the use of open textbooks. Table 1 below outlines themes that emerged from the open-ended questions related to student performance. Themes not associated with open textbooks, such as lab or teaching methods, were excluded.

Table 1

Thematic Analysis on Student Performance Related to Using Open Textbooks

\begin{tabular}{|c|c|c|}
\hline Performance & Themes & Illustrative data \\
\hline Better & $\begin{array}{l}\text { - Easy access } \\
\text { - Alignment } \\
\text { - Improved } \\
\text { - scores/grades } \\
\text { - Easy-to-use } \\
\text { - Change in } \\
\text { pedagogy/approach } \\
\text { - Read/used the text } \\
\text { - More student } \\
\text { engagement } \\
\text { - More homework time }\end{array}$ & $\begin{array}{l}\text { - I noticed a fairly significant improvement in the average scores for } \\
\text { the first exam. (I have taught the class many times using a } \\
\text { traditional textbook.) I have attributed this to the fact that more } \\
\text { students are reading [the textbook] than they have in the past. } \\
\text { - They [students] are prepared for the first class and do not fall } \\
\text { behind waiting for financial aid disbursements for their books. }\end{array}$ \\
\hline Same & $\begin{array}{l}\text { - Similar to previous } \\
\text { text } \\
\text { - Same content } \\
\text { - Show up to class } \\
\text { - Students still did not } \\
\text { read text }\end{array}$ & $\begin{array}{l}\text { - Regardless of the style of textbook, the students will interact in the } \\
\text { same way, either they will read it or they won't. What has changed } \\
\text { is how much I can refer to the books because every student can } \\
\text { afford to purchase the book. } \\
\text { - Many students are not reading the textbooks anyway. The } \\
\text { strongest correlation with performance seems to be effort spent on } \\
\text { homework, rather than on the particular textbook. }\end{array}$ \\
\hline Worse & $\begin{array}{l}\text { - Lower quiz scores } \\
\text { - Increased student } \\
\text { cheating } \\
\text { - Poor editorial quality } \\
\text { - Poor illustration or } \\
\text { figure quality } \\
\text { - Poor alignment }\end{array}$ & $\begin{array}{l}\text { - I have read three [open textbooks] in my area, and used two of } \\
\text { them. I was disappointed in the poor quality of all three of them. } \\
\text { You can tell that there is a lack of editing done by skilled, } \\
\text { knowledgeable people. } \\
\text { - There are many factual errors, misuse of terms, obvious lack of } \\
\text { understanding of basic scientific principles, and more. The artwork } \\
\text { is very poor and many of the links are broken, have been } \\
\text { withdrawn, or are so simplistic as to be useless. }\end{array}$ \\
\hline
\end{tabular}


Since decreasing student drop/withdrawal/incompletion rates have been a central concern to institutions, we were interested in identifying what factors might contribute to faculty members' perceptions related to student performance when using open textbooks. Faculty responses to a general question about student retention were similar to responses related to student performance. Overall, $71 \%$ of the faculty members believed that the student drop/withdrawal/incomplete rates stayed the same when utilizing open textbooks as opposed to traditional textbooks. $18 \%$ of the faculty members thought these rates had decreased.

Another finding not directly related to student performance, but repeatedly identified by respondents, was the significant affective impact on students when using open textbooks. Manu faculty reported their students highly appreciated open textbooks, which faculty perceived as a positive impact on student learning.

\section{Use}

We examined how faculty use open textbooks, how often faculty members perceive that the students use the open textbooks, and faculty members' future intentions to continue using open textbooks. Of the faculty members in the study, $57 \%$ provided their students with links to download or read the textbooks on mobile devices or in web browsers. In addition, $13 \%$ of the faculty members reported that they adapted, modified, and/or improved the open textbooks, indicating that they made the time and effort necessary to tailor the open textbook for optimal use in their particular courses (see Figure 5).

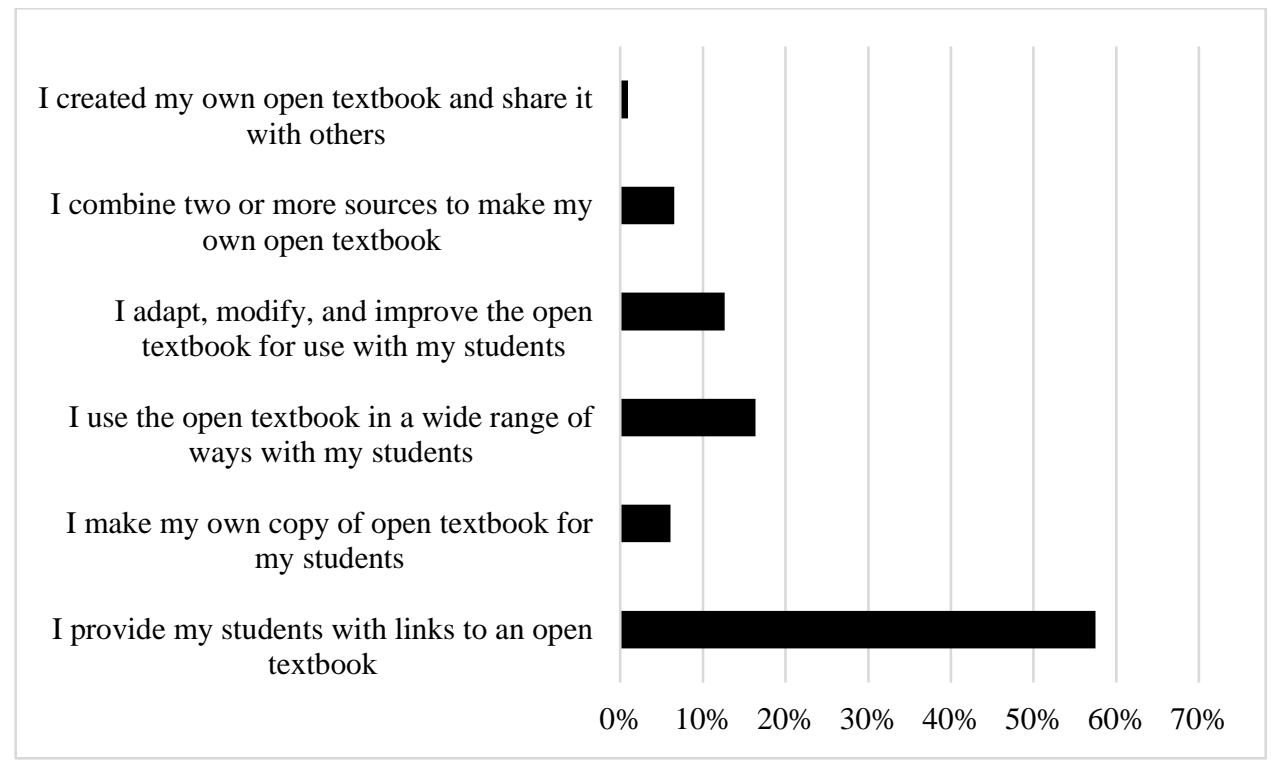

Figure 5. Faculty use of open textbooks.

Overall, about $80 \%$ of the faculty members believed that using open textbooks was at least as good as or better than using traditional textbooks. Half of the faculty members perceived that the students used the open textbooks as often as their traditional textbooks, while $28 \%$ of the faculty members believed that the students used them more often. 
In addition, a strong intention exists among the surveyed faculty members in regard to continued use of open textbooks in the future: $87 \%$ mentioned that they are extremely likely to continue using open textbooks, while $7 \%$ stated that they are somewhat likely to use them again.

\section{Perception of Quality}

Survey questions related to perception of quality were based on Bliss et al.'s (2013) work, with additional constructs added from conversations with OpenStax (OpenStax, personal communication, August 10, 2016). The relationships among perception of quality, adoptability, and student performance were newly added in this study.

Perception of open textbook quality. Of the surveyed faculty members, $62 \%$ thought that open textbooks have about the same quality as traditional textbooks, whereas $19 \%$ thought they have better quality. Figure 6 illustrates the faculty members' perception of the quality of the open textbooks.



Figure 6. Faculty members' perceptions of the quality of open textbooks.

A deeper analysis was conducted in order to identify the respondents' general perceptions of the quality of open textbooks as well as the rationale for these perceptions (See Table 2). 
Table 2

Faculty Members' Perceptions of the Quality of Open Textbooks

\begin{tabular}{|c|c|c|}
\hline Quality & Themes & Illustrative data \\
\hline Better & $\begin{array}{l}\text { - Design } \\
\text { - Interactivity } \\
\text { - Readability } \\
\text { - Navigation } \\
\text { - Supplementary materials } \\
\text { - Quality of content } \\
\text { - The ability to customize } \\
\text { - Modernity } \\
\text { - User-friendliness } \\
\text { - Clear explanations } \\
\text { - Updated content } \\
\text { - Portable/accessible/responsive } \\
\text { - design }\end{array}$ & $\begin{array}{l}\text { - I believe that there is probably little difference in the content } \\
\text { that is presented; however, open texts have the very real } \\
\text { advantage of being improved/updated continuously. The } \\
\text { content can be tailored to better suit the student/instructor } \\
\text { needs. Finally, open texts seem to be a bit more user-friendly } \\
\text { to students to find and when using the ancillary features (e.g., } \\
\text { study guides, practice questions, slide presentations). } \\
\text { - The... anatomy and physiology [open] textbook comes close } \\
\text { to the quality of my favorite (Pearson's Marieb). It does not } \\
\text { have the graphic quality, but I can get these [graphics] in } \\
\text { other ways, including using the Visible body app, which is } \\
\text { cheaper than a textbook. Since my students do not have to } \\
\text { purchase the text, they can afford this app, which comes out } \\
\text { to be } \$ 35 \text { over a two semester class or } \$ 17 \text { a semester. BUT } \\
\text { the app is theirs forever. They can use it to continue to review } \\
\text { and study outside of class. }\end{array}$ \\
\hline Same & $\begin{array}{l}\text { - Same level of quality } \\
\text { - Same content } \\
\text { - Objectives } \\
\text { - Similar organization } \\
\text { - Similar visuals/media } \\
\text { - Reputable authors } \\
\text { - Peer reviewed } \\
\text { - Readability } \\
\text { - Similar mistakes between } \\
\text { - } \text { Sublished and open textbooks } \\
\text { - Same learning objectives } \\
\text { Same publishing process }\end{array}$ & $\begin{array}{l}\text { - The writing is more concise and better organized in the [open } \\
\text { textbook], but the graphics are not as polished. I really like } \\
\text { the embedded links to the multimedia content in the online } \\
\text { version of [the open textbook]. [Publisher's] online quizzing } \\
\text { through [publisher's LMS] is more advanced/refined, but a } \\
\text { pain to set up. [OER provider tools... are] much easier to use } \\
\text { and [sufficient] for my needs. } \\
\text { - The content is fairly similar among all of the textbooks for the } \\
\text { subject matter. There is very little variation among the } \\
\text { textbooks I have reviewed. }\end{array}$ \\
\hline Worse & $\begin{array}{l}\text { - Lack essential materials } \\
\text { - Outdated research/teaching } \\
\text { methods } \\
\text { - Poor editorial quality } \\
\text { - Poor figures/illustrations } \\
\text { - Lack of supplemental materials } \\
\text { - Lack of multimedia materials } \\
\text { - Alignment between the content } \\
\text { and user's need }\end{array}$ & $\begin{array}{l}\text { - I teach Anatomy and Physiology and the textbooks are very } \\
\text { visually oriented. Artwork for scientific texts can be very } \\
\text { expensive to produce, so this [the graphics] is a primary area } \\
\text { where the book we use is lacking compared to the } \\
\text { mainstream publishers' texts. } \\
\text { - Primarily the figures. Relying on free diagrams is very } \\
\text { difficult. For science you absolutely need excellent diagrams } \\
\text { and tables to understand the material. There is also not } \\
\text { enough thought put into how things are taken by people of } \\
\text { different racial, ethnic backgrounds or gender. The book that } \\
\text { I used previously had many editions and had thought about it } \\
\text { more consistently. We cannot use it in the next general } \\
\text { biology course because the figures for the phylogenies are not } \\
\text { up to date and accurate enough for our course. }\end{array}$ \\
\hline
\end{tabular}

In response to the question "How would you rate the quality of the open textbook used in your course," $62 \%$ indicated the open textbook was about the same quality as the textbooks they used in their other courses, while $19 \%$ indicated the open textbook was better in quality. Among those who indicated the same quality, $62 \%$ believed open textbooks are generally the same quality as textbooks they use in other courses. Among 
those who indicated the better quality, $48 \%$ stated open textbooks are generally better in quality than textbooks they use in other courses. Of the $17 \%$ who believed their open textbook was worse in quality than texts used in their other courses, 32\% said open textbooks are worse in quality. However, a large percent of respondents across the follow-up questions indicated they do not know if open textbooks are worse (40\%), the same (22.99\%), or better (41.94\%) than traditional textbooks.

Perception of quality and adoption intentions. We also examined whether the quality of open textbooks would potentially cause faculty members to adopt them. Ninety one percent of faculty respondents would adopt open textbooks when quality was at least equal to traditional textbooks, which is well aligned with the previous finding on faculty intention to continue using open textbooks (See Figure 7).

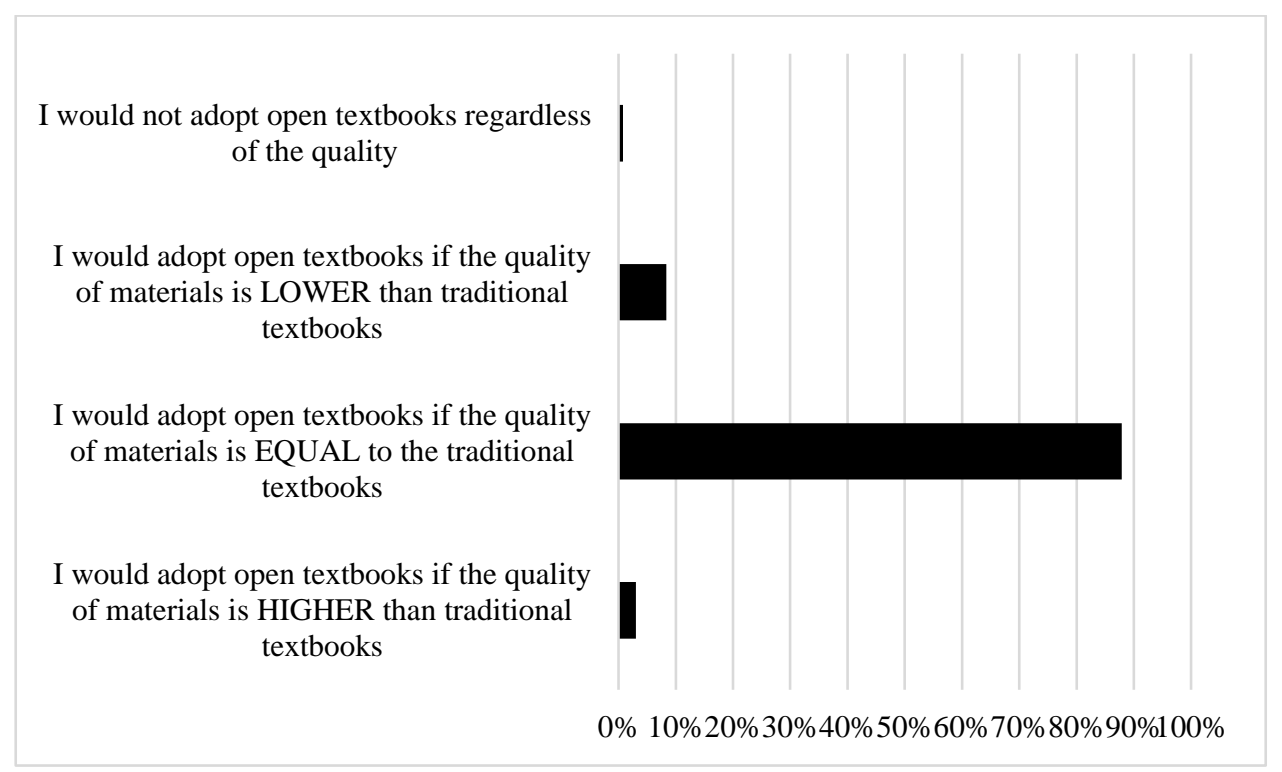

Figure 7. Perception of quality and adoption intentions.

Perception of quality and student performance. In regard to whether open textbooks impact student performance, $49 \%$ of the faculty respondents believed that the quality of open textbooks positively impacted student performance, while 30\% believed quality did not impact student performance. Only $3 \%$ of the faculty members said that the quality of the open textbooks negatively impacted student performance. Eighteen percent of the faculty members reported that they did not know whether the quality of the open textbooks impacted student performance.

Characteristics of open textbook quality. We also explored what factors contribute to the perception of the quality of open textbooks. Table 3 summarizes the faculty members' responses. Cost and affordability (75\%) were ranked highest in importance, followed by content quality (66\%), content difficulty (55\%), readability (53\%), and scope/sequence (49\%). 
Table 3

Characteristics of Open Textbook Quality

\begin{tabular}{lccccc}
\hline \multicolumn{1}{c}{ Question } & $\begin{array}{c}\text { Extremely } \\
\text { important }\end{array}$ & $\begin{array}{c}\text { Very } \\
\text { important }\end{array}$ & $\begin{array}{c}\text { Moderately } \\
\text { important }\end{array}$ & $\begin{array}{c}\text { Slightly } \\
\text { important }\end{array}$ & $\begin{array}{c}\text { Not at all } \\
\text { important }\end{array}$ \\
\hline Content quality & $66 \%$ & $31 \%$ & $3 \%$ & $0 \%$ & $0 \%$ \\
Scope/sequence & $49 \%$ & $40 \%$ & $10 \%$ & $1 \%$ & $0 \%$ \\
Content difficulty & $55 \%$ & $40 \%$ & $5 \%$ & $1 \%$ & $0 \%$ \\
Readability & $53 \%$ & $37 \%$ & $8 \%$ & $1 \%$ & $0 \%$ \\
Cost/affordability & $75 \%$ & $17 \%$ & $6 \%$ & $2 \%$ & $1 \%$ \\
Accessibility features & $36 \%$ & $22 \%$ & $32 \%$ & $8 \%$ & $3 \%$ \\
Appealing visuals & $22 \%$ & $30 \%$ & $35 \%$ & $11 \%$ & $2 \%$ \\
Illustration/media & $30 \%$ & $35 \%$ & $22 \%$ & $10 \%$ & $2 \%$ \\
Interactive elements & $24 \%$ & $32 \%$ & $26 \%$ & $12 \%$ & $6 \%$ \\
Author reputation & $5 \%$ & $15 \%$ & $29 \%$ & $34 \%$ & $18 \%$ \\
Peer-reviewed content & $25 \%$ & $36 \%$ & $25 \%$ & $10 \%$ & $3 \%$ \\
Example problems & $39 \%$ & $37 \%$ & $10 \%$ & $6 \%$ & $8 \%$ \\
Review questions & $35 \%$ & $39 \%$ & $12 \%$ & $8 \%$ & $5 \%$ \\
Available ancillaries & $17 \%$ & $38 \%$ & $24 \%$ & $14 \%$ & $7 \%$ \\
Online homework & $16 \%$ & $23 \%$ & $29 \%$ & $13 \%$ & $19 \%$ \\
Available in print & $22 \%$ & $23 \%$ & $32 \%$ & $12 \%$ & $11 \%$ \\
\hline
\end{tabular}

\section{Accessibility of Open Textbooks}

Higher education institutions have become increasingly aware of the importance of accessibility. With the increase in open textbooks users, we believe that faculty perception of accessibility is critical. Questions associated with accessibility in our study focused on: (1) awareness of the accessibility features of open textbooks, (2) the types of student disabilities, (3) the number of students with disabilities, (4) confidence in regard to the accessibility features of open textbooks, and (5) the relationship between accessibility and intention of open textbook adoption.

Awareness of the accessibility features of open textbooks. More than half of the faculty members perceived open textbooks as either fully or mostly accessible, while the remaining faculty members (53\%) were unsure as to their level of accessibility to students with disabilities. However, cautious interpretation of the results is advisable since the term "accessibility" can be interpreted differently depending on individual understanding.

Types of student disabilities. For the question "When teaching courses using open textbooks, for what types of disabilities have your students needed accommodations? Check all that apply," the most commonly reported disabilities were cognitive (24\%), followed by visual (18\%), auditory (17\%), and physical 
(12\%). Responses that were not applicable (e.g., "more time on exams" or "none this semester") were excluded from the results.

Number of students with disabilities. All of the faculty members were asked how many students they had in their courses using open textbooks. Answers that did not indicate a specific number were excluded from the results. We calculated the median for the range response, such as "2-3." On average, the faculty members were likely to have 1.52 students with some sort of disability $(M=1.52, S D=2)$.

In regards to types of accommodations made for students with disabilities when using open textbooks, many faculty reported no textbook accommodations were necessary, while some reported providing cognitive accommodations like extended time on tests/assignments. Other faculty indicated open textbook accommodations were needed for students with auditory or physical disabilities such as using screen readers/enlarging text, displaying captions, utilizing keyboard navigation. A couple of faculty cited advantages for students with disabilities when using open textbooks over traditional textbooks including the ability to search faster and to interact more with the textbook using highlighting and other features.

Confidence regarding the accessibility features of open textbooks. Another related question asked how confident faculty members were regarding assessing the accessibility features of open textbooks. Half of the faculty members (50\%) stated that they knew what features to look for when determining whether or not an open textbook is accessible to students with disabilities. However, $27 \%$ of the faculty members did not know what accessibility features to look for, but knew where to go to ask for help, while $22 \%$ of the faculty members stated that they did not know what to look for or where to find help.

Accessibility and intention of open textbook adoption. The final accessibility question focused on whether faculty members' intention to adopt open textbooks was influenced by accessibility features. About a quarter of the faculty member stated that accessibility features were an important consideration when adopting an open textbook. About a half (49\%) of the faculty members said that accessibility features would likely impact their adoption decisions, while $21 \%$ of the faculty members said that accessibility features would not impact their decisions.

\section{Discussion}

Access to higher education is still a privilege for some students. Noting that a high portion of faculty participants in this study work at community colleges and public institutions, affordability is an important aspect when it comes to adopting open textbooks. Since open textbooks are primarily distributed in an electronic format, students do not have to wait to receive financial aid funding prior to purchasing such textbooks and can access open textbooks before the course officially begins. Faculty members in this study reported students often read open textbooks on their mobile devices and in web browsers. Providing immediate and ubiquitous access to open textbooks may play a role in the improvement of student performance as well as impact faculty expectations of student learning. 
Faculty members also benefit from using open textbooks. Several faculty members stated that open textbooks provided easy navigation and keyword searches, and helped them better present lectures or complete in-class exercises together with students. In addition, faculty members reported that using open textbooks improved their pedagogies through the use of more hands-on and authentic learning experiences, or through flipped classroom or active learning approaches. Changing in-class activities indicates a significant implication when using open textbooks in addition to cost reduction. Further investigation is highly recommended with regard to pedagogy and open textbooks.

However, the lack of supplementary materials has been raised by faculty respondents as an important issue. Recent conversations with OpenStax revealed the development of a dedicated community of open textbook adopters whereby share their supplementary materials with others. Over time, this may make a significant contribution to the emergence of a sustainable OER community.

Mixed results were reported in regards to alignment and assessment. That is, some faculty members mentioned the open textbooks they used were better aligned with their teaching, whereas others stated the opposite. Regardless, results from our study suggest faculty members carefully review open textbooks before adoption, as customizations may be needed. In fact, we believe that customizations may be essential for open textbooks to flourish for at least two reasons- (1) learning is contextual, and (2) reluctance from faculty who need supplemental materials.

Finally, many faculty reported affective responses from students. Several faculty members stated students appreciated their efforts to help make textbooks affordable. Without measurement, the direct effects of student appreciation remain undiscovered, but may positively contribute to student motivation and attitude toward completing their education. Further study is needed to investigate and directly measure how student preparation and performance may be impacted by the use of quality open textbooks.

\section{Implications}

Research on open textbooks has focused on outcome-oriented studies, and findings from this study suggest a new direction. Beyond the inherent cost saving, we have found that utilizing open textbooks can enable innovative instructional approaches, such as flipped classroom or collaborative learning using hands-on activities. Potentially based on the assumption that everyone has a textbook, faculty may hold students more accountable and encourage students to take a strong sense of ownership for their learning. Given the nature of our survey method, we were unable to determine why many faculty members perceived an enhancement in student performance.

Therefore, future research should focus on identifying the relationships between increased student performance and the use of open textbooks. With the findings revealed, scholars could enrich the OER knowledge base and begin contemplating pedagogical suggestions, while reducing the cost of education. Awareness of OER is more widespread than previously thought, which indicates a need for an elaboration on the instructional approaches related to its use. As researchers in the field of OER, we hope that this 
article encourages more educators and scholars to collectively advance the data on the optimal use of open textbooks.

\section{Limitations}

This study has some limitations. First, we utilized convenient sampling - the survey respondents were specifically targeted as users of certain OER providers, such as OpenStax. Thus, all of the adopters already had some experience with open textbooks, which may have caused a biased sample as adopters likely have a positive attitude toward open textbooks. Second, this study investigated faculty perceptions. Although perceptions can reveal meaningful data, a few areas exist in which perceptions cannot articulate real phenomena. For example, faculty confidence related to the accessibility features of open textbooks is entirely subjective without the use of direct measurements. Third, limitations exist in self-reported data. One such limitation includes the introspective ability of the participants (i.e., they may lack the ability to accurately reflect on the past) (Merriam, 1998). However, while we admittedly report limitations, it is equally important to note that we strove to secure instrument validity through expert reviews as well as data validation using the member-checking method (Bliss, Robinson, Hilton, \& Wiley, 2013) in order to lessen the bias of the self-reported data and subjectiveness of the qualitative data analysis (Creswell, 2003; Merriam, 1998).

\section{Conclusion}

This study contributes to the OER literature by examining how faculty members perceive the use of open textbooks from a particular leading OER provider-OpenStax. Overall, the findings suggest that a significant amount of financial saving and pedagogical shifts exist with the use of open textbooks. In addition, the results show that some students are perceived to spend more time reading the book, which the faculty members believe is of equal or greater quality than traditional textbooks. Some faculty members also perceived that students were better prepared for class and performed at least as well as, if not better, when using traditional textbooks.

One of the primary benefits of OER is to reduce the educational cost for students. Compared to cost reduction, percentages of perceived student performance improvement, preparedness, and textbook quality are not significantly high. However, it is evident that adopting an open textbook is no harm, and thus worth implementing. However, additional research is needed to empirically determine whether open textbooks help student performance, not merely faculty perception of student performance. As the knowledge base of OER adoption continues to be enriched, the need exists for deeper, more specific, and diversified empirical studies in multiple contexts. 


\section{References}

Allen, I. E., \& Seaman, J. (2016). Opening the textbook: Educational resources in U.S. higher education, 2015-16. Retrieved from http://www.onlinelearningsurvey.com/reports/openingthetextbook2016.pdf

Allen, I. E., Seaman, J., Poulin, R., \& Straut, T. T. (2016). Online report card: Tracking online education in the United States. Babson Survey Research Group and Quahog Research Group, LLC. Retrieved from http://onlinelearningsurvey.com/reports/onlinereportcard.pdf.

Coolidge, A., Doner, S., \& Robertson, T. (2015). B.C. open textbook accessibility toolkit. British Columbia: BCcampus. Retrieved from http://opentextbc.ca/accessibilitytoolkit/

Bliss, T., Robinson, T., Hilton, J., \& Wiley, D. (2013). An OER COUP: College teacher and student perceptions of open educational resources. Journal of Interactive Media in Education, 2013(1).

Bok, D. (2009). Universities in the marketplace: The commercialization of higher education. Princeton, NJ: Princeton University Press.

Buczynski, J. A. (2007). Faculty begin to replace textbooks with "freely" accessible online resources. Internet Reference Services Quarterly, 11(4), 169-179.

Caswell, T. (2012). The open course library of the Washington State Colleges. In D. G. Oblinger (Ed.), Game changers: Education and information technologies (pp. 259-262). Retrieved from http://www.educause.edu/Resources/GameChangersEducationandInform/CaseStudy2TheOpen CourseLibrary.

Creswell, J. W. (2003). Research design: Qualitative, quantitative, and mixed method approaches. Thousand Oaks, California: Sage Publications.

D’Antoni, S. (2009). Open educational resources: Reviewing initiatives and issues. The Journal of Open and Distance Learning, 24, 3-10.

de los Arcos, B., Farrow, R., Pitt, R., Weller, M., \& McAndrew, P. (2016). Personalising learning through adaptation: Evidence from a global survey of K-12 teachers' perceptions of their use of open educational resources. Journal of Online Learning Research, 2(1), 23-40.

Hilton III, J., \& Wiley, D. (2011). Open access textbooks and financial sustainability: A case study on Flat World Knowledge. The International Review of Research in Open and Distributed Learning, 12(5), 18-26.

Hilton III, J., Robinson, T. J., Wiley, D., \& Ackerman, J. D. (2014). Cost-savings achieved in two semesters through the adoption of open educational resources. The International Review of Research in Open and Distributed Learning, 15(2). 1-18. 
Hilton, J. III. (2016). Open educational resources and college textbook choices: A review of research on efficacy and perceptions. Educational Technology Research and Development, 64(4), 573-590.

Nevo, B. (1985). Face validity revisited. Journal of Educational Measurement, 22(4), 287-293.

Merriam, S. B. (1998). Qualitative research and case study applications in education, San Francisco, CA: Jossey-Bass Publishers.

Paulsen, M. B., \& St John, E. P. (2002). Social class and college costs: Examining the financial nexus between college choice and persistence. The Journal of Higher Education, 73(2), 189-236.

Pitt, R. (2015). Mainstreaming open textbooks: Educator perspectives on the impact of OpenStax college open textbooks. The International Review of Research in Open and Distributed Learning, 16(4).

Provasnik, S., and Planty, M. (2008). Community colleges: Special supplement to the condition of education 2008. National Center for Education Statistics, Washington, DC, Institute of Education Sciences, U.S. Department of Education.

\section{Athabasca University}

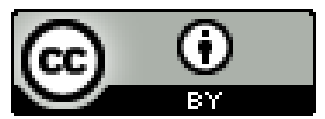

